\title{
INTEGRASI REPRESENTASI MAKROSKOPIK, PARTIKEL, DAN SIMBOLIK PADA BAHAN AJAR LARUTAN ASAM-BASA MENGGUNAKAN PENDEKATAN MODEL LEARNING CYCLE $5 E$ UNTUK KELAS XI
}

Rosmala Hapsah, Rukaesih Ahmad Maolani, Arif Rahman

Jurusan Kimia, Fakultas Matematika dan Ilmu Pengetahuan Alam, Universitas Negeri Jakarta, Jalan Pemuda no 10, Rawamangun 13220, Jakarta, Indonesia.

Corresponding Author:ros_uruwashi@yahoo.com

\begin{abstract}
Abstrak
Integrasi representasi makroskopik, partikel, dan simbolik dapat membatu siswa menghubungkan antar ketiga representasi dari suatu fenomena. Penelitian ini menghasilkan bahan ajar Larutan Asam-Basa melalui integrasi representasi makroskopik, partikel, dan simbolik dengan model Learning Cycle 5E yang layak untuk kelas XI. Bahan ajar ini dapat dijadikan sumber belajar alternatif pada pembelajaran kimia. Penelitian dilakukan di Universitas Negeri Jakarta, SMAN 39 Jakarta, dan MAN 14 Jakarta sejak bulan Februari hingga November 2012. Metode penelitian yang digunakan adalah metode penelitian pengembangan. Metode ini terdiri dari tiga tahap yaitu analisis kebutuhan, pengembangan bahan ajar, dan uji coba kelayakan bahan ajar. Hasil perhitungan reliabilitas interrater pada uji materi, uji media, dan uji bahasa di tahap pengembangan bahan ajar, masingmasing menunjukkan bahwa kesesuaian antar penilai baik, $r>0.7$. Selain itu hasil interpretasi skor pada tahap uji coba kelayakan menunjukkan bahwa bahan ajar layak digunakan. Berdasarkan hasil tersebut, dapat disimpulkan bahwa bahan ajar yang telah dikembangkan dapat diterima dengan baik dan layak.
\end{abstract}

Kata Kunci:

Bahan Ajar, Larutan Asam-Basa, Representasi Kimia, Learning Cycle 5E, Penelitian Pengembangan.

\begin{abstract}
Integrating of macroscopic, particulate, and symbolic representations can help student to understand how the representations of phenomena are related. This study produced Acid-Base Solution learning material through integrating macroscopic, particulate, and symbolic representations with Learning Cycle 5E model which proper for $11^{\text {th }}$ grade. Product can be used as alternative learning source for chemistry. This study conducted since February to November 2012 at State University of Jakarta, SMAN 39 Jakarta, and MAN 14 Jakarta. The method of this study is Research and Development. This method divided into three phases; need assessment, development of learning material, and test feasibility of learning material. In the phases of test to the assessor in development of learning material resulted coefficient reliability is $r>0.7$. Besides, feasibility test shows that product can be used. According to the results can be concluded that product is acceptable for $11^{\text {th }}$ grade.
\end{abstract}

Keywords:

Learning Material, Acid-Base Solution, Chemical Representation, Learning Cycle 5E, Research and Development.

\section{Pendahuluan}

Materi kimia dapat dipelajari dalam tiga level representasi, yaitu makroskopik, partikel, dan simbolik [1]. Level makroskopik meliputi fenomena yang dapat diamati menggunakan panca indera. Level partikel meliputi fenomena molekuler yang tidak dapat diindera secara langsung. Sedangkan level simbolik meliputi lambang, nomor, rumus, persamaan, dan struktur dari suatu fenomena kimia. Lihat Gambar 1. Guru dapat dengan mudah menghubungkan antar ketiga representasi dari suatu materi, namun siswa lebih memilih untuk mempelajari kimia dari satu level saja yakni makroskopik. Perbedaan inilah yang menimbulkan banyak kesulitan ketika mengajar kimia [2].

Beberapa guru kimia berasumsi bahwa siswa sudah familiar dengan representasi makroskopik sehingga pengajaran (sekitar 70\%) difokuskan pada level simbolik [1][3]. Asumsi tersebut menyebabkan (sekitar 70,84\%) siswa sulit memahami kimia karena mereka tidak dapat menghubungkan ketiga representasi dari suatu fenomena. Para peneliti berusaha mengatasi masalah tersebut dengan cara 
mengintegrasikan ketiga level representasi ketika proses pembelajaran berlangsung. Hasil penelitian yang telah dilakukan mengindikasikan bahwa dengan mengintegrasikan ketiga representasi materi dapat meningkatkan pemahaman konsep siswa, namun hingga kini bahan ajar yang membahas ketiga representasi materi belum tersedia.

Berdasarkan hasil analisis yang dilakukan pada lima buku kimia dalam materi Larutan AsamBasa, menunjukkan keberadaan representasi di level partikel kurang difokuskan (sekitar 15\%). Hal tersebut menjadi sebuah masalah ketika penggunaan bahan ajar seperti buku, modul, dan LKS, sesuai dengan gaya belajar siswa yang umumnya visual (sekitar 96,67\%). Siswa membutuhkan catatan, gambar, diagram, grafik, demonstrasi atau ilustrasi/animasi dibandingkan dengan penjelasan verbal agar lebih memahami materi. Oleh karena itu perlu dilakukan pengembangan bahan ajar visual melalui integrasi representasi makroskopik, partikel, dan simbolik untuk membantu siswa dalam memahami konsep pada materi Larutan AsamBasa.

Pengembangan bahan ajar Larutan Asam-Basa melalui integrasi representasi makroskopik, partikel, dan simbolik dilakukan dengan model Learning Cycle 5E. Bahan ajar dengan model Learning Cycle $5 E$ terdiri dari lima fase pembelajaran, yakni engagement (perencanaan), exploration (penyelidikan), explanation (penjelasan), elaboration (penerapan), dan evaluation (penilaian). Bahan ajar dengan model ini sebelumnya telah digunakan oleh Rosari (2007) untuk pengembangan bahan ajar pada materi Ikatan Kimia [4]. Karakter dari materi ini bersifat konseptual sama seperti Larutan Asam-Basa. Oleh karena itu, diharapkan dengan menerapkan kelima fase pembelajaran yang dikembangkan dari teori konstruktivisme dapat membantu siswa menghubungkan ketiga representasi pada materi Larutan Asam-Basa untuk meningkatkan pemahaman konsep mereka.

Berdasarkan latar belakang tersebut, penulis melakukan pengembangan bahan ajar Larutan Asam-Basa melalui integrasi representasi makroskopik, partikel, dan simbolik dengan model Learning Cycle $5 E$ untuk kelas XI.

\section{Metodologi Penelitian}

Tujuan operasional penelitian ini untuk menyusun, menilai, dan melakukan uji coba kelayakan terhadap bahan ajar Larutan AsamBasa melalui integrasi representasi makroskopik, partikel, dan simbolik dengan model Learning Cycle $5 E$ untuk siswa SMA/MA kelas XI. Penelitian dilakukan di Universitas Negeri Jakarta pada bulan Februari - Desember 2012. Tahap analisis kebutuhan dilakukan pada bulan Maret 2012 di SMA Negeri 39 Jakarta, sedangkan uji coba kelayakan bahan ajar di SMA Negeri 39 Jakarta dan MAN 14 Jakarta pada bulan November 2012. Metode yang digunakan adalah metode penelitian pengembangan (Research and Development), yaitu penelitian tentang pembuatan suatu produk dan penyempurnaannya [5].

Prosedur pelaksanaan pengembangan bahan ajar meliputi beberapa tahap, yakni analisis kebutuhan, pengembangan bahan ajar, dan uji coba kelayakan bahan ajar. Analisis kebutuhan dilakukan melalui analisis representasi materi pada buku kimia SMA dan menyebar angket kepada siswa dan guru. Tahap pengembangan bahan ajar terdiri dari analisis kurikulum, analisis materi, penyusunan skenario, pembuatan bahan ajar, penilaian

internal, dan uji kepada penilai materi, bahasa, dan media. Sedangkan tahap uji coba kelayakan bahan ajar dilakukan kepada guru, siswa kelompok kecil, dan siswa kelompok besar.

Data diperoleh dengan menggunakan instrumen berupa angket tertutup, dimana pernyataanpernyataan telah memiliki alternatif jawaban (option) yang akan dipilih oleh responden [6]. Instrumen yang digunakan dalam penelitian pengembangan ini berupa:

\section{a. Instrumen Analisis Kebutuhan}

Analisis kebutuhan menggunakan dua instrumen. Instrumen pertama berupa instrumen analisis buku teks kimia yang bertujuan untuk mengetahui bentuk representasi materi yang ada dalam buku teks tersebut. Instrumen analisis buku mengacu 
pada penilaian buku yang telah dikembangkan oleh Gkitzia et,al. (2011) dan Niaz \& Maza (2011) [7][8]. Instrumen kedua berisi pernyataan-pernyataan yang bertujuan untuk mengetahui kebutuhan siswa dan guru dalam pembelajaran kimia agar bahan ajar yang dikembangkan sesuai dengan kebutuhan. Instrumen-instrumen ini merupakan bahan acuan tahap penelitian selanjutnya.

Tabel 1. Penafsiran Fleiss.

\begin{tabular}{|c|l|}
\hline $\mathbf{r}$ & \multicolumn{1}{|c|}{ Kesepakatan } \\
\hline $0.0-0.20$ & Buruk \\
\hline $0.21-0.40$ & Kurang dari sedang \\
\hline $0.41-0.60$ & Sedang \\
\hline $0.61-0.80$ & Baik \\
\hline $0.81-1.00$ & Sangat baik \\
\hline
\end{tabular}

b. Instrumen Uji Kelayakan kepada Para Penilai Instrumen uji kelayakan ini mengacu pada penilaian bahan ajar oleh Badan Standar Nasional Pendidikan. Penilaian isi bahan ajar meliputi aspek materi, bahasa, dan media. Pendapat para penilai akan dianalisis dan dijadikan sebagai masukan untuk perbaikan bahan ajar.

c. Instrumen Uji Kelayakan kepada Guru dan Siswa

Instrumen uji kelayakan ini ditujukan kepada siswa dan guru SMA sebagai objek yang menggunakan produk berupa bahan ajar yang telah dikembangkan. Dari hasil analisis ini didapatkan data kelayakan produk sebagai bahan evaluasi untuk perbaikan selanjutnya.

Instrumen yang digunakan pada penelitian ini sudah valid dan reliabel, namun pada tahap pengambilan data penelitian dilakukan pengujian reliabilitas antar rater Intraclass Correlation Coefficient (ICC) dari Fleiss Kappa. Cara mengukur rata-rata kesepakatan antar rater dengan ICC menggunakan rumus $r$ [9].

$$
\mathrm{r}=\frac{\mathrm{RJK}_{\mathrm{b}}-\mathrm{RJK}_{\mathrm{e}}}{\mathrm{RJK}_{\mathrm{b}}}
$$

Keterangan: $r=$ koefisien kesepakatan antar rater; $\mathrm{RJK}_{\mathrm{b}}=$ Jumlah kuadrat baris, dan $\mathrm{RJK}_{\mathrm{e}}=$ Jumlah kuadrat error.

Setelah didapatkan nilai rata-rata kesepakatan antar rater, nilai tersebut dibandingkan dengan nilai kategori kesepakatan menurut Fleiss (Tabel 1) [10].

Teknik analisis data pada penelitian ini menggunakan teknik deskriptif analisis yang dilakukan terhadap hasil analisis kebutuhan, pengembangan bahan ajar, dan uji coba kelayakan bahan ajar.

Tabel 2. Hasil Analisis Representasi Materi Pada Buku Kimia SMA/MA.

\begin{tabular}{|c|c|c|c|}
\hline \multirow{2}{*}{ Kriteria } & \multicolumn{3}{|c|}{ Klasifikasi } \\
\cline { 2 - 4 } & $\begin{array}{c}\text { Tidak ada } \\
(\%)\end{array}$ & $\begin{array}{c}\text { Ada } \\
(\%)\end{array}$ & $\begin{array}{c}\text { Baik } \\
(\%)\end{array}$ \\
\hline K1 & 20 & 73 & 7 \\
\hline K2 & 27 & 33 & 40 \\
\hline K3 & 40 & 13 & 47 \\
\hline K4 & 27 & 20 & 53 \\
\hline K5 & 67 & 33 & 0 \\
\hline
\end{tabular}

\section{Hasil dan Pembahasan}

\section{Analisis Kebutuhan}

Tahap analisis kebutuhan bertujuan untuk mengetahui kebutuhan apa saja yang diperlukan untuk mengatasi masalah-masalah dalam kegiatan pembelajaran. Ada dua kegiatan dalam analisis ini, yaitu tinjauan pustaka dan survei lapangan.

\section{a. Tinjauan Pustaka}

Analisis dilakukan untuk mengetahui sejauh mana keberadaan ketiga representasi kimia dalam buku yang digunakan oleh siswa pada materi Larutan Asam-Basa. Buku yang dianalisis yakni, buku kimia SMA kelas XI karangan Michael Purba (2007); J.M.C. Johari dan M. Rachmawati (2007); Sandri Justiana dan Muchtaridi (2009); Budi Utami et.al. (2011); dan Tarti Harjani (2012). Ketiga representasi yang ada dalam buku teks dievaluasi dengan menggunakan lima kriteria. Kriteria tersebut adalah: (K1) keberadaan representasi materidalam buku teks; (K2) kejelasan interpretasi tampilan representasi materi; (K3) hubungan representasi materi dengan teks; (K4) keberadaan dan sifat dari suatu keterangan representasi materi; dan (K5) hubungan antar representasi materi. Kriteria ini didasarkan pada 
penelitian yang dilakukan oleh Gkitzia et.al dalam The Royal Society of Chemistry [7].

Berdasarkan lima kriteria analisis representasi materi yang dilakukan, maka dapat diketahui hasil analisis sebagai berikut: (Tabel 2 )

Berdasarkan Tabel 2 dapat diketahui hasil analisis representasi materi pada kelima buku teks kimia, sebagai berikut: (1) Keberadaan masing-masing ketiga representasi materi Larutan Asam-Basa pada kelima buku teks kimia, sebanyak 20\% tidak ada representasi, 73\% ada pada kelima buku namun tidak terdapat pada seluruh indikator pembelajaran, dan $7 \%$ terdapat representasi materi pada seluruh indikator pembelajaran. Umumnya (46\%) representasi materi yang ada dalam ketiga buku teks kimia adalah level simbolik. Keberadaan representasi materi pada level makroskopik sebesar 39\% dan level partikel hanya 15\%. Hasil ini menunjukkan bahwa yang menjadi fokus dalam ketiga buku teks kimia adalah representasi materi pada level simbolik dan makroskopik.

Tabel 3. Hasil Analisis Representasi Materi Pada Bahan Ajar yang Dikembangkan.

\begin{tabular}{|c|c|c|c|}
\hline \multirow{2}{*}{ Kriteria } & \multicolumn{3}{|c|}{ Klasifikasi } \\
\cline { 2 - 4 } & $\begin{array}{c}\text { Tidak ada } \\
(\mathbf{\%})\end{array}$ & $\begin{array}{c}\text { Ada } \\
(\mathbf{\%})\end{array}$ & $\begin{array}{c}\text { Baik } \\
(\mathbf{\%})\end{array}$ \\
\hline K1 & 0 & 0 & 100 \\
\hline K2 & 0 & 50 & 50 \\
\hline K3 & 0 & 0 & 100 \\
\hline K4 & 0 & 0 & 100 \\
\hline K5 & 0 & 0 & 100 \\
\hline
\end{tabular}

(2) Kejelasan interpretasi dari bentuk representasi yang ditampilkan, 27\% tidak ada kejelasan, 33\% ada kejelasan namun tidak seluruh bagian dari representasi dijelaskan, dan $40 \%$ representasi diinterpretasikan secara baik. Kriteria ini penting diperhatikan ketika menggambarkan suatu representasi, agar siswa dapat memahami secara benar arti/interpretasi yang digambarkan.

(3) Seluruh representasi memiliki hubungan dengan teks (47\%), meskipun masih terdapat representasi yang seluruhnya tidak berhubungan dengan teks (40\%) dan 13\% ada representasi materi yang ditampilkan tidak berhubungan dengan teks. Hal ini menunjukkan bahwa representasi yang di tampilkan dari kelima buku teks mampu menghubungkan keterkaitan dengan konsep, prinsip, atau fenomena yang dimuat dalam teks.

(4) Keberadaan dan sifat dari sebuah keterangan representasi materi, umumnya (53\%) sudah baik menjelaskan representasi yang di tampilkan. Sehingga siswa memahami representasi tanpa harus membaca teks sebelumnya. Namun sebanyak $27 \%$ representasi tidak memiliki keterangan yang jelas dan $20 \%$ keterangan hanya menunjukkan masalah atau topik yang dipelajari tanpa menjelaskan secara luas. (5) Umumnya (67\%) ketiga representasi tidak memiliki keterkaitan ketika menjelaskan satu indikator pembelajaran. Namun 33\% hanya dua representasi yang berhubungan dan tidak ada (0\%) yang ketiga representasi memiliki keterkaiatan ketika menjelaskan satu indikator pembelajaran. Sehingga siswa masih sulit untuk menghubungkan ketiga representasi kimia yang ada.

\section{b. Survei Lapangan}

Survei lapangan untuk mengetahui karakteristik metode pengajaran yang diterima oleh siswa dan bahan ajar yang sering digunakan di kelas. Hasil angket yang telah diberikan kepada siswa dan guru dapat diketahui bahwa $74,17 \%$ siswa tertarik mempelajari kimia, namun 70,84\% dari mereka tidak memahami tentang materi kimia, dan 70,84\% mengalami kesulitan dalam memahami konsep-konsep yang ada pada materi. Umumnya 96,67\% siswa memiliki gaya belajar visual dan $80,84 \%$ kinestetik sedangkan verbal sebanyak $26,67 \%$.

Selain itu hasil angket menunjukkan bahwa dalam kegiatan belajar di kelas, bahan ajar yang sering digunakan oleh guru adalah bahan ajar visual (100\%) seperti buku, modul, LKS, dan lainnya. Bahan ajar multimedia (21,67\%) seperti flash dan audio-visual $(12,50 \%)$ seperti film juga digunakan dalam pembelajaran, namun bahan ajar audio seperti kaset tape recorder, radio, dan lainnya tidak digunakan di kelas. Guru dan siswa berpendapat bahwa penggunaan bahan ajar cukup membantu (46,67\%) untuk memahami materi yang sedang dipelajari dan dapat memotivasi siswa $(69,17 \%)$. 
Berdasarkan hasil angket kebutuhan dapat diketahui bahwa penggunaan bahan ajar visual seperti buku, modul, dan LKS, sesuai dengan gaya belajar siswa. Mereka membutuhkan catatan, gambar, diagram, grafik, demonstrasi atau ilustrasi/animasi dibandingkan dengan penjelasan verbal agar lebih memahami materi. Selain itu penggunaan bahan ajar dapat membantu dan memotivasi siswa untuk mempelajari materi kimia. Namun tinjauan pustaka mengidentifikasi bahwa buku yang digunakan saat ini belum dapat menghubungkan ketiga representasi

materi dalam setiap indikator pembelajaran, khususnya pada materi Larutan Asam-Basa. Penyajian materi yang tidak menghubungkan ketiga representasi kimia merupakan salah satu faktor siswa mengalami kesulitan memahami konsep-konsep yang ada. Oleh karena itu perlu adanya pengembangan bahan ajar visual melalui integrasi representasi makroskopik, partikel, dan simbolik untuk membantu siswa dalam memahami konsep pada materi Larutan Asam-Basa.

\section{Pengembangan Bahan Ajar}

Tahap pengembangan bahan ajar bertujuan untuk menghasilkan bahan ajar yang siap di uji coba kelayakannya kepada guru dan siswa.

\section{a. Perencanaan Bahan Ajar}

Tahap ini untuk menghasilkan rancangan produk yang akan dikembangkan. Ada beberapa langkah untuk mencapai tujuan ini, yaitu analisis kurikulum dan analisis materi.

Hasil analisis menunjukkan bahwa enam materi pokok di sebelas indikator pembelajaran bersifat konseptual, tiga bersifat prosedural, dan dua bersifat faktual. Selain itu karakter dari materi Larutan Asam-Basa bersifat ingatan, pemahaman, penerapan, dan analisis. Jika melihat karakter dari materi Larutan Asam-Basa, maka diperlukan model pembelajaran yang dapat meningkatkan pemahaman konsep siswa. Penelitian ini menggunakan model Learning Cycle 5E untuk tujuan tersebut.

Berdasarkan hasil analisis kurikulum dan materi, dibuat suatu rancangan bahan ajar yang terdiri dari lima materi pembelajaran, yaitu asam dan basa, kekuatan asam-basa, pH Larutan, Air bersih, dan teori asam-basa Brónsted-Lowry dan Lewis. Setiap materi pembelajaran disusun berdasarkan model Learning Cycle 5E dan disajikan dengan tiga representasi kimia pada setiap indikator pembelajaran.

\section{b. Pengembangan Bahan Ajar}

Penyusunan materi pada bahan ajar dilakukan sesuai dengan skenario pengembangan bahan ajar. Bahan ajar berukuran A4 dibuat dengan menggunakan Microsoft Word 2007 dan Adobe Photoshop CS-4. Setelah dibuat, bahan ajar dinilai berdasarkan penilaian representasi materi seperti menganalisis representasi materi pada buku teks kimia di tahap analisis kebutuhan. Penilaian ini dilakukan oleh dua penilai. Penilaian bertujuan untuk melihat kesuaian bahan ajar dengan skenario dan hubungan antar ketiga representasi materi yang telah ditampilkan. Hasil dari penilaian ini diketahui bahwa representasi materi yang di tampilkan pada bahan ajar sudah baik dan sesuai dengan model Learning Cycle 5E. Hasil penilaian ini dapat dilihat (tabel 3).

Berdasarkan Tabel 3 dapat diketahui hasil penilaian representasi materi pada bahan ajar yang dikembangkan sebagai berikut: (1) Keberadaan masing-masing ketiga representasi materi Larutan Asam-Basa pada bahan ajar yang telah dikembangkan, sudah terdapat pada seluruh indikator pembelajaran. Hasil ini menunjukkan bahwa ketiga representasi materi sudah difokuskan dalam bahan ajar.

(2) Kejelasan interpretasi dari bentuk representasi yang ditampilkan 50\% ada kejelasan namun tidak seluruh bagian dari representasi dan 50\% representasi diinterpretasikan secara baik. Bagian inilah yang merupakan kekurangan dari bahan ajar yang dikembangkan.

(3) Seluruh representasi memiliki hubungan dengan teks. Hal ini menunjukkan bahwa representasi yang di tampilkan dari bahan ajar sudah mampu menghubungkan keterkaitan dengan konsep, prinsip, atau fenomena yang dimuat dalam teks.

(4) Keberadaan dan sifat dari sebuah keterangan representasi materi, sudah baik 
menjelaskan representasi yang di tampilkan. Sehingga siswa memahami representasi tanpa harus membaca teks sebelumnya.

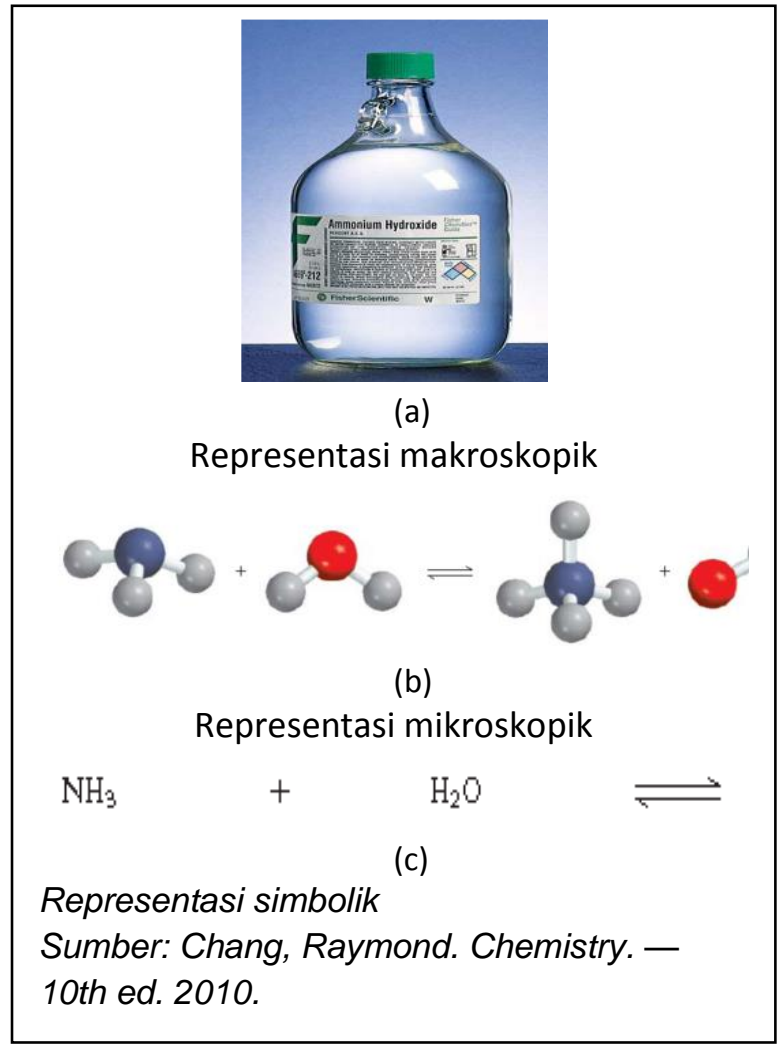

Gambar 1. Contoh Ketiga Representasi Amonia.

(5) Ketiga representasi telah ditampilkan memiliki keterkaiatan ketika menjelaskan satu indikator pembelajaran. Sehingga membantu siswa menghubungkan ketiga representasi kimia yang ada.

Setelah bahan ajar yang dibuat sudah sesuai dengan skenario dan representasi yang ditampilkan sudah baik, selanjutnya dinilai oleh para penilai.

\section{c. Uji Penilaian Bahan Ajar}

Kegiatan ini dilakukan untuk mengetahui kesepakatan antar rater dalam menilai kualitas bahan ajar yang telah dikembangkan. Penilaian dilakukan oleh penilai yang kompeten di bidangnya dan dilakukan pada waktu yang telah disesuaikan oleh masing-masing penilai. Instrumen yang digunakan untuk menilai bahan ajar mengacu pada penilaian Badan Standar Nasional Pendidikan (BSNP) yang sudah valid dan reliabel.
Penilaian ini meliputi uji materi, bahasa, dan media. Uji ini dilakukan oleh sepuluh responden yang terdiri dari dosen, guru kimia, dan lulusan S1 pendidikan kimia. Hasil uji penilaian bahan ajar diketahui bahwa kesesuaian antar penilai dalam menilai kualitas bahan ajar sudah baik, dengan nilai $r>70$. Hasil kesesuaian antar rater ini dapat disimpulkan bahwa bahan ajar telah layak untuk digunakan.

\section{Uji Coba Kelayakan Bahan Ajar}

Uji coba kelayakan bahan ajar bertujuan untuk menguji kelayakan, memperoleh pendapat dan masukan dari para responden tentang bahan ajar yang telah dikembangkan. Responden untuk uji coba terdiri dari guru dan siswa di SMA N 39 Jakarta dan MAN 14 Jakarta. Uji coba yang dilakukan dengan cara memberikan bahan ajar yang telah dinilai oleh para penilai pada tahap sebelumnya, kemudian responden mengisi angket yang telah disediakan sebagai hasil penilaian.

Penilaian pada uji coba kelayakan meliputi enam indikator yang masing-masing terdapat beberapa sub-indikator. Indikator pertama yaitu kelayakan isi dengan sub indikator kesesuaian uraian materi dengan SK, KD, dan tujuan pembelajaran, keakuratan materi, dan materi pendukung pembelajaran. Indikator kedua yaitu kelayakan penyajian meliputi sub-indikator teknik penyajian, penyajian pembelajaran, dan kelengkapan penyajian. Indikator ketiga yaitu kelayakan bahasa dengan sub indikator kesesuaian bahasa dengan tingkat perkembangan siswa, komunikatif, serta keruntutan dan kesatuan gagasan. Indikator keempat yaitu ukuran bahan ajar dengan sub indikator ukuran fisik bahan ajar. Indikator kelima yaitu kulit bahan ajar meliputi subindikator tata letak, tipografi, dan ilustrasi kulit bahan ajar. Indikator keenam yaitu desain isi bahan ajar meliputi tata letak, tipografi, dan ilustrasi isi bahan ajar.

a. Uji coba kelayakan bahan ajar kepada guru

Uji ini dilakukan kepada sepuluh responden. Berdasarkan uji coba kelayakan bahan ajar kepada guru, kualitas bahan ajar dikatakan baik apabila skor tiap butir pernyataan lebih $\geq 30$. Dari hasil perhitungan diketahui bahwa sebanyak 22 butir pernyataan menghasilkan 
skor $\geq 30$. Jadi dapat disimpulkan bahwa kualitas bahan ajar sudah baik dan layak untuk digunakan oleh guru kimia.

b. Uji coba kelayakan bahan ajar kepada siswa

Uji coba kelayakan kepada siswa bertujuan menguji kelayakan dan mengetahui pendapat siswa mengenai bahan ajar yang telah dikembangkan. Uji coba kelayakan ini dilakukan oleh siswa MAN 14 Jakarta dan SMA N 39 Jakarta dengan cara memberikan bahan ajar yang telah dinilai oleh para penilai kemudian mereka menilainya. Uji ini meliputi uji coba kelayakan bahan ajar kepada siswa kelompok kecil dan kelompok besar.

Uji coba siswa kelompok kecil dilakukan kepada 10 siswa yang diambil secara acak di MAN 14 Jakarta. Kualitas bahan ajar dikatakan baik apabila skor tiap butir soal $\geq 30$. Hasil perhitungan diketahui bahwa $63,6 \%$ butir soal menghasilkan skor maksimum yang berarti bahwa kualitas bahan ajar baik. Meskipun kualitas bahan ajar sudah baik, namun perlu adanya perbaikan pada butir soal yang memiliki skor < 30. Setelah mengetahui kekurangan dari bahan ajar yang dikembangkan, lalu dilakukan perbaikan sebelum uji coba kelayakan kepada siswa kelompok besar.

Uji coba kelompok besar dilakukan kepada 75 siswa yang diambil secara acak dari siswa di MAN 14 Jakarta dan SMA N 39 Jakarta. Kualitas bahan ajar dikatakan baik apabila skor tiap butir soal uji ini $\geq 225$. Hasil perhitungan diketahui bahwa 90,9\% butir soal menghasilkan skor maksimum yang berarti bahwa kualitas bahan ajar baik. Meskipun kualitas bahan ajar sudah baik, namun perlu adanya perbaikan pada butir soal yang memiliki skor $<225$.
Berdasarkan hasil uji coba kelayakan kepada siswa kelompok kecil dan besar, dapat disimpulkan bahwa kualitas bahan ajar sudah baik dan layak untuk digunakan oleh siswa.

\section{Kesimpulan dan Saran}

\section{Kesimpulan}

Bahan ajar Larutan Asam-Basa melalui integrasi representasi makroskopik, partikel, dan simbolik dengan model Learning Cycle $5 E$ layak untuk SMA/MA kelas XI. Bahan ajar ini telah disusun, dinilai, dan diuji coba kelayakannya kepada siswa dan guru. Ada lima materi pembelajaran dalam bahan ajar ini, yaitu asam dan basa, teori asam-basa Brónsted-Lowry dan Lewis, kekuatan asam-basa, pH larutan, dan air bersih. Setiap materi disusun mengikuti kelima fase pembelajaran dalam model Learning Cycle $5 E$ (yaitu pendahuluan, eksplorasi, penjelasan, penerapan konsep, dan evaluasi) dan dilengkapi dengan tiga representasi kimia (yaitu representasi makroskopik, partikel, dan simbolik).

\section{Saran}

Untuk penelitian selanjutnya, dapat dilakukan pengujian efektivitas bahan ajar dalam meningkatkan pemahaman konsep siswa pada materi Larutan Asam-Basa. Selain itu dapat juga dilakukan penelitian pengembangan bahan ajar melalui integrasi representasi makroskopik, partikel, dan simbolik dengan model Learning Cycle 5E untuk materi lain.

\section{Penghargaan}

Peneliti mengucapkan terimakasih kepada pihak Jurusan Kimia Fakultas Matematika dan IImu Pengetahuan Alam Universitas Negeri Jakarta, SMA Negeri 39 Jakarta, dan Madrasal Aliyah Negeri 14 Jakarta.

\section{Daftar Pustaka}

[1] Johnstone, A.H. 2010. "You Can't Get There from Here". Journal of Chemical Education. Vol. 87, No. 1, 22-28.

[2] Jong, O.D. dan Driel, J.V. 1999. The development of preservice teachers' concerns about teaching chemistry topics at a macro-micro-representational interface, in 'Proceedings of the Second International Conference of the European Science Education Research Association, Research in Science Education: 31 Agustus - 4 September, 1999, Kiel, Jerman. http://www.ipn.unikiel.de /projekte/esera/book/191-dej.pdf.

[3] Gabel, D. 2005. "Enhanching Students' Conceptual Understanding of Chemistry through Integrating the Macroscopic, Particle, and Symbolic Representations of Matter". Dalam Pienta, 
N. J., Cooper M. M., dan Greenbowe T. J. (Eds), Chemists' Guide to Effective Teaching II. Pearson Prentice Hall, New Jersey: 77-87.

[4] Rosari, I. 2011. Pengembangan Modul Pembelajaran Kimia SMA Kelas X Pada Pokok Bahasan Ikatan Kimia dengan Model Learning Cycle 5E. Universitas Negeri Jakarta. Jakarta: ix+131 hlm.

[5] Arikunto, S. 2002. Prosedur Penelitian: Suatu Pendekatan Praktek. Asidi Mahasatya, Jakarta: v + $342 \mathrm{hlm}$.

[6] Sukmadinata, N. S. 2009. Metode Penelitian Pendidikan. Remaja Rosdakarya, Bandung: ix +326 hlm.

[7] Gkitzia, V., Katerina S., dan Chryssa T. 2011. "Development and Application of Suitable Criteria for The Evaluation of Chemical Representastions in School Textbooks". The Royal Society of Chemistry. Vol.12, 5-14.

[8] Niaz, M. dan Maza A. 2011. Nature of Science in General Chemistry Textbook. Springer, New York: viii $+43 \mathrm{hlm}$.

[9] Djaali dan Pudji M. 2008. Pengukuran dalam Bidang Pendidikan. Grasindo, Jakarta: vii + 170 hlm.

[10] Widiarso, W. 2005. Reliabilitas Antar Rater. Presentasi Power Point. Http://Widhiarso.Staff.Ugm.Ac.Id/Files/Reliabilitas Antar Rater.Pdf (diakses tanggal 20 Februari 2012). 